\title{
PENGARUH TRANSFORMASI EKONOMI TERHADAP SPESIALISASI DAN PENYERAPAN TENAGA KERJA KOTA-KOTA DI PROVINSI SUMATERA SELATAN
}

\author{
Oleh: Evi Rosiana \\ (BADAN PUSAT STATISTIK PROVINSI SUMATERA SELATAN)
}

evirosiana@yahoo.com

\begin{abstract}
Abstrak-Penelitian ini bertujuan untuk menganalisis pengaruh transformasi ekonomi terhadap spesialisasi dan penyerapan tenaga kerja kota-kota di Provinsi Sumatera Selatan. Guna menjawab permasalahan penelitian digunakan metode analisis regresi data panel selama 8 tahun yaitu dari Tahun 2006 hingga Tahun 2013 mencakup seluruh kota di Provinsi Sumatera Selatan yaitu Kota Palembang, Kota Prabumulih, Kota Pagar Alam dan Kota Lubuk Linggau. Penghitungan nilai spesialisasi menunjukkan bahwa sektor ekonomi yang terspesialisasi di seluruh kota di Sumatera Selatan adalah sektor jasa. Hasil estimasi model pengaruh transformasi ekonomi terhadap spesialisasi dan penyerapan tenaga kerja menunjukkan bahwa transformasi ekonomi yang terjadi pada sektor pertanian dan jasa berpengaruh signifikan dan positif terhadap spesialisasi dan penyerapan tenaga kerja sedangkan transformasi ekonomi sektor industri berpengaruh signifikan dalam arah yang negatif terhadap spesialisasi dan penyerapan tenaga kerja sektor industri.
\end{abstract}

Kata Kunci: Transformasi Ekonomi, Spesialisasi, Penyerapan

\begin{abstract}
This study aims to analyze the effect of economic transformation on specialization and employment of cities in South Sumatra Province. To answer the research problem the panel data regression analysis method is used for 8 years, from 2006 to 2013 covering all cities in South Sumatra Province, namely Palembang City, Prabumulih City, Pagar Alam City and Lubuk Linggau City. The calculation of specialization value shows that the economic sector that is specialized in all cities in South Sumatra is the service sector. The estimation results of the model of the effect of economic transformation on specialization and employment shows that the economic transformation that occurs in the agriculture and services sectors has a significant and positive effect on specialization and employment, while the economic transformation of the industrial sector has a significant effect on the negative direction of specialization and employment industrial sector.
\end{abstract}

Keywords: Economic Transformation, Specialization, Absorption 


\section{PENDAHULUAN}

Provinsi Sumatera Selatan sebagai provinsi dengan nilai PDRB Tahun 2013 terbesar ke-9 di Indonesia juga telah mengalami transformasi struktural yang berjalan tidak seiring dengan perubahan struktur penyerapan tenaga kerja (Yunisvita, 2011). Transformasi struktural yang terjadi terlihat dari penurunan kontribusi sektor primer di Provinsi Sumatera Selatan yang diikuti kenaikan sektor sekunder dan tersier. Permasalahannya adalah besarnya kontribusi sektor sekunder terhadap perekonomian Sumatera Selatan tidak berimbang dengan kemampuannya dalam menyerap tenaga kerja. Sektor primer yang berkontribusi sebesar 38,45 persen dipaksa menyerap lebih dari 50 persen tenaga kerja di Provinsi Sumatera Selatan sedangkan sektor sekunder yang berkontribusi sebesar 26,54 persen hanya mampu menyerap tenaga kerja sebesar 8,91 persen saja. Ray (1998) mengemukakan bahwa masyarakat yang tinggal di daerah perkotaan umumnya bekerja di sektor industri dan jasa, maka rendahnya kemampuan sektor sekunder dalam menyerap tenaga kerja akan berdampak pada pengangguran di perkotaan.

Berdasarkan data ketenagakerjaan Provinsi Sumatera Selatan Tahun 2013 diketahui bahwa Tingkat Pengangguran Terbuka (TPT) daerah perdesaan di Provinsi
Sumatera Selatan lebih rendah dibandingkan daerah perkotaan. Diduga di daerah perdesaan karena didominasi oleh sektor pertanian, penyerapan tenaga kerja relatif tinggi. Penduduk usia kerja dengan mudah dapat bekerja di sektor pertanian meskipun sebagai pekerja keluarga atau pekerja bebas (buruh tani) karena tidak membutuhkan keahlian atau pendidikan yang tinggi. Sebaliknya di daerah perkotaan lapangan pekerjaan formal lebih selektif dalam menerima tenaga kerja khususnya dengan tingkat pendidikan yang dipersyaratkan (BPS Provinsi Sumatera Selatan, 2013)

Tingkat pengangguran di Provinsi Sumatera Selatan umumnya lebih tinggi di kota-kota, yaitu di Kota Palembang, Kota Prabumulih, Kota Pagaralam dan Kota Lubuk Linggau. Tingginya tingkat pengangguran akan menimbulkan masalah sosial dan kependudukan sehingga perlu ditemukan solusi yang tepat dalam hal penyediaan lapangan kerja di kota. Berdasarkan hal tersebut maka penelitian ini akan mengkaji mengenai permasalahan penyerapan tenaga kerja sektoral di kota-kota di Provinsi Sumatera Selatan, yaitu apakah transformasi ekonomi yang terjadi di kota-kota di Provinsi Sumatera Selatan berpengaruh terhadap spesialisasi serta penyerapan tenaga kerja sektoralnya. 
Model pertumbuhan ekonomi dengan penawaran tenaga kerja yang tidak terbatas Lewis didasarkan pada dikotomi antara sektor subsisten dan modern. Pada sektor modern maksimalisasi keuntungan dalam pasar kompetitif berdasarkan dalil ahli ekonomi neo klasik yaitu tenaga kerja dibayar nilai produk marjinalnya. Permintaan tenaga kerja pada sektor ini bergantung dari ketersediaan modal, kemajuan teknologidan permintaan barangbarang industri,sedangkan pada sektor subsisten terdapat kelebihan penawaran tenaga kerja. Situasi ini memastikan penawaran tenaga kerja yang elastis sempurna dari sektor subsisten ke sektor modern. Jika sektor modern ingin menarik pekerja, maka sektor modern tersebut harus membayar upah sedikit lebih tinggi di atas level subsisten sebagai kompensasi biaya hidup yang lebih tinggi di sektor modern ketimbang di sektor subsisten (Kien, 2014)

Teori Transformasi Ekonomi Terjadinya perubahan struktur ekonomi ini juga dapat dilihat dari perubahan kontribusi setiap sektor terhadap PDB/PDRBnya, dimana sektor-sektor tersebut umumnya dikelompokkan menjadi sembilan sektor, dan dalam penelitian ini akan dikelompokkan menjadi tiga sektor yakni sektor pertanian, industri dan jasa.

Kingombe dan Velde (2013) menyatakan bahwa beberapa kebijakan dapat mewujudkan transformasi dan inovasi tetapi tidak memberikan pengaruh signifikan terhadap kesempatan kerja, sementara kebijakan lainnya dapat menciptakan kesempatan kerja namun dengan kualitas yang rendah. Kuncinya adalah menciptakan dan menerapkan kebijakan yang tepat yang dapat menciptakan lapangan kerja sekaligus mewujudkan transformasi struktural. Dari uraian di atas maka peneliti mengadakan penelitian dengan judul "Pengaruh Transformasi Ekonomi Terhadap Spesialisasi Dan Penyerapan Tenaga Kerja Kota-Kota Di Provinsi Sumatera Selatan".

\section{METODE PENELITIAN}

Penelitian ini mengambil obyek penelitian kota-kota di Provinsi Sumatera Selatan yaitu Kota Palembang, Kota Prabumulih, Kota Pagaralam dan Kota Lubuk Linggau untuk Tahun 2006 sampai dengan tahun 2013. Sesuai dengan model yang dikembangkan dalam penelitian ini maka alat analisis data yang digunakan adalah analisis regresi data panel dengan menggunakan Eviews

Penelitian ini menggunakan data sekunder, yaitu data yang berasal dari publikasi Badan Pusat Statistik (BPS) Provinsi Sumatera Selatan seperti Produk Domestik Regional Bruto (PDRB), Daerah Dalam Angka, Indikator Kesejahteraan Rakyat, Buku Saku Data serta Publikasi Indikator Sosial 
Sumatera Selatan. Data yang digunakan adalah data Tahun 2006 hingga tahun 2013 untuk kota-kota di Provinsi Sumatera Selatan yaitu Kota Palembang, Kota Prabumulih, Kota Pagaralam dan Kota Lubuk Linggau.

Teknik Analisis Data Location Quotient dapat menunjukkan besar kecilnya peranan sektor perekonomian suatu region dengan membandingkan sektor yang sama pada wilayah yang lebih besar. Analisis LQ ini merupakan alat analisis untuk menunjukkan basis ekonomi wilayah terutama dari kriteria kontribusi. Banyak variabel yang bisa diperbandingkan, tetapi secara umum adalah nilai tambah dan jumlah lapangan kerja. LQ merupakan tekhnik perhitungan yang mudah untuk menunjukkan spesialisasi relatif (kemampuan) wilayah dalam kegiatan atau karakteristik tertentu (Rondinelli, 1985). Menurut Isard et al (1998), karena kesederhanannya LQ sangat berguna pada tahap awal penelitian, adapun rumusannya adalah sebagai berikut :

$$
L Q=\frac{Y_{i, j} / Y_{j}}{Y_{i} / Y}
$$

keterangan

$\mathrm{Y}_{\mathrm{i}, \mathrm{j}}$ : Kesempatan kerja sektor i di kota j

$Y_{j}$ : Total kesempatan kerja di Kota j

$Y_{i}$ : Kesempatan kerja sektor i di Provinsi Sumatera Selatan
Y : Total kesempatan kerja di Provinsi Sumatera Selatan

Setelah Location Quotient (LQ) dihitung maka kesimpulan yang didapat adalah :

1. LQ > 1, berarti sektor tersebut dapat dikatakan sektor potensial (sektor basis), menunjukkan suatu sektor mampu memenuhi kebutuhan sendiri/lokal juga dapat memenuhi daerah lain.

2. LQ $<1$, berarti sektor tersebut dapat dikatakan bukan sektor potensial (sektor non basis).

3. $\mathrm{LQ}=1$, berarti suatu sektor hanya mampu melayani kebutuhan lokal, menunjukkan keswasembadaan(self-

sufficiency) sektor tersebut di suatu daerah.

\section{Analisis Shift Share}

Dengan teknik ini, selain dapat mengamati penyimpanganpenyimpangan dari berbagai perbandingan kinerja perekonomian antar wilayah, keunggulan kompetitif (competitive advantage) suatu wilayah juga dapat diketahui melalui tenik analisis Shift-Share ini (Thoha dan Soekarni, 2000). Metode analisis shift share diawali dengan mengukur perubahan nilai tambah bruto atau PDRB suatu sektor - i di suatu region - $\mathrm{j}\left(\mathrm{D}_{\mathrm{ij}}\right)$ dengan formulasi (Soepono, 1993) :

$$
D_{i j}=N_{i j}+M_{i j}+C_{i j} \ldots \ldots \ldots(2)
$$

\section{Keterangan :}




$$
\begin{aligned}
\mathrm{D}_{\mathrm{i}, \mathrm{j}}: & \text { Perubahan sektor i di } \\
& \text { wilayah } \mathrm{j} \\
\mathrm{N}_{\mathrm{i}, \mathrm{j}}: & \text { Pertumbuhan sektor } \mathrm{i} \text { di } \\
& \text { wilayah } \mathrm{j} \text { yang disebabkan } \\
& \text { oleh pengaruh pertumbuhan } \\
& \text { ekonomi } \\
& \text { nasional/provinsi } \\
\mathrm{M}_{\mathrm{i}, \mathrm{j}}: & \text { Bauran industri sektor } \mathrm{i} \text { di } \\
& \text { wilayah } \mathrm{j} \\
\mathrm{C}_{\mathrm{i}, \mathrm{j}}: & \text { Keunggulan kompetitif } \\
& \text { sektor i di wilayah } \mathrm{j}
\end{aligned}
$$
$\mathrm{C}_{\mathrm{i}, \mathrm{j}}$ : Keunggulan kompetitif sektor i di wilayah $\mathrm{j}$

\section{Dimana}

$$
\begin{aligned}
& N_{i j}=E_{i j} \cdot r_{n} \ldots \ldots . . \\
& M_{i j}=E_{i j}\left(r_{i n}-r_{n}\right) \\
& C_{i j}=E_{i j}\left(r_{i j}-r_{i n}\right)
\end{aligned}
$$

Dari persamaan (3) sampai (5), $\mathrm{r}_{\mathrm{ij}}$ mewakili pertumbuhan tenaga kerja sektor i di wilayah j, sedangkan $r_{n}$ dan $r_{i n}$ masing-masing laju pertumbuhan tenaga kerja agregat nasional/provinsi dan pertumbuhan sektor i secara nasional/provinsi, yang masing-masing dapat didefinisikan sebagai berikut:

$$
\begin{aligned}
& r_{i j}=\left(E_{i j, t}-E_{i j}\right) / E_{i j} \\
& r_{i n}=\left(E_{i n, t}-E_{i n}\right) / E_{i n} \\
& r_{n}=\left(E_{n, t}-E_{n}\right) / E_{n} \ldots
\end{aligned}
$$

\section{Keterangan \\ $E_{\mathrm{ij}}$ : Tenaga kerja sektor i di wilayah j (kabupaten/kota) tahun awal analisis \\ $\mathrm{E}_{\mathrm{in}}$ : Tenaga kerja sektor i di wilayah regional (Provinsi) tahun awal analisis \\ $\mathrm{E}_{\mathrm{n}}$ : Total tenaga kerja di wilayah regional (Provinsi) tahun awal analisis}
$\mathrm{E}_{\mathrm{ij}, \mathrm{t}}$ : Tenaga kerja sektor $\mathrm{i}$ di wilayah j(kabupaten/kota) tahun akhir analisis
$E_{\text {in,t: }}$ Tenaga kerja sektor i di wilayah regional (Provinsi) tahun akhir analisis
$E_{n, t}$ : Total tenaga kerja di wilayah regional (Provinsi) tahun akhir analisis

Persamaan (3) sampai (5) juga menunjukkan bahwa peningkatan nilai tambah suatu sektor di suatu wilayah $\left(\mathrm{D}_{\mathrm{ij}}\right)$ dapat diuraikan (decompose) menjadi 3 faktor berpengaruh, yaitu (Sjafrizal, 2002) :

\section{Regional Share $\left(\mathbf{N}_{\mathrm{ij}}\right)$ \\ 2. Proportional Shift $\left(\mathbf{M}_{\mathbf{i j}}\right)$ \\ 3. Differential Shift $\left(\mathbf{C}_{\mathbf{i j}}\right)$}

Melalui ketiga komponen tersebut dapat diketahui komponen atau unsur pertumbuhan yang mana yang mempengaruhi pertumbuhan ekonomi daerah. Nilai masingmasing komponen dapat saja negatif atau positif, tetapi jumlah keseluruhan akan selalu positif, bila pertumbuhan ekonomi juga positif dan begitu pula sebaliknya. Berdasarkan persamaan (2) sampai (8) di atas, maka untuk suatu wilayah, pertumbuhan nasional atau regional, bauran industri dan keunggulan kompetitif dapat ditentukan bagi suatu sektor i atau dijumlah untuk semua sektor sebagai keseluruhan wilayah. Persamaan Shift-Share untuk sektor i di wilayah j adalah: 


$$
\begin{aligned}
D_{i j}= & E_{i j} \cdot r_{n}+E_{i j}\left(r_{i n}-r_{n}\right)+E_{i j}\left(r_{i j}-\right. \\
& \left.r_{i n}\right) \ldots .(9)
\end{aligned}
$$

Selanjutnya untuk mengetahui tingkat spesialisasi perekonomian di suatu daerah juga dapat dilakukan dengan modifikasi analisis shiftshare ini. Esteban Marguillas pada tahun 1972 telah melakukan modifikasi terhadap teknik analisis Shift-share untuk memecahkan masalah pengaruh efek alokasi dan spesialisasi (Soepono, 1993). Dengan mengacu kepada persamaan (2) sampai (9), maka modifikasi persamaan Shift-Share menurut Estaban Marguillas mengandung unsur baru yang diberi notasi $\mathrm{E}^{*}{ }_{\mathrm{ij}}$ didefinisikan sebagai suatu variabel wilayah $\left(\mathrm{E}_{\mathrm{ij}}\right)$, bila struktur wilayah sama dengan struktur nasional atau $E_{i j}=E^{*} i j$ maka $E^{*} \mathrm{ij}$ dirumuskan menjadi :

$$
E^{*}{ }_{i j}=E_{j}\left(E_{i n} / E_{n}\right)
$$

Apabila Eij diganti dengan $\mathrm{E}^{*} \mathrm{ij}$ maka persamaan $C_{i j}=E_{i j}\left(r_{i j}-r_{i n}\right)$ dapat pula diganti menjadi :

$$
\mathbf{C}^{*}{ }_{\mathrm{ij}}=\mathbf{E}^{*}{ }_{\mathrm{ij}}\left(\mathbf{r}_{\mathrm{ij}}-\mathbf{r}_{\mathrm{in}}\right)
$$

$\mathrm{C}_{\mathrm{ij}}$ adalah untuk mengukur keunggulan atau ketidakunggulan kompetitif di sektor i pada perekonomian di suatu wilayah menurut analisis Shift-share klasik. Pengaruh efek alokasi (allocation effect) belum dijelaskan dari suatu variabel wilayah untuk sektor $\mathrm{i}$ di wilayah $\mathrm{j}\left(\mathrm{A}_{\mathrm{ij}}\right)$, untuk mengetahui efek alokasi tersebut didekati dengan menggunakan rumus (Soepono, 1993:41) :

$$
\mathbf{A}_{\mathrm{ij}}=\left(\mathbf{E}_{\mathrm{ij}}-\mathbf{E}^{*}{ }_{\mathrm{ij}}\right)\left(\mathbf{r}_{\mathrm{ij}}-\mathbf{r}_{\mathrm{in}}\right)
$$

Keterangan :

- $\left(\begin{array}{lll}E_{i j} & -E^{*}{ }_{i j}\end{array}\right):$ menggambarkan tingkat spesialisasi sektor i di wilayah $\mathrm{j}$

- $\left(r_{i j}-r_{i n}\right)$ :menggambarkan tingkat keunggulan kompetitif sektor i di wilayah $\mathrm{j}$

$\mathrm{A}_{\mathrm{ij}}$ sebagai pengaruh alokasi dapat dilihat dalam dua bagian yaitu tingkat spesialisasi sektor i di wilayah $\mathrm{j}\left(\mathrm{E}_{\mathrm{ij}}-\mathrm{E}^{*}{ }_{\mathrm{ij}}\right)$ yang dikalikan dengan keunggulan kompetitif $\left(\mathrm{r}_{\mathrm{ij}}-\right.$ $r_{\text {in }}$ ). Persamaan tersebut dapat bermakna bilasuatu wilayah mempunyai suatu spesialisasi di sektor tertentu, maka sektor tersebut pasti akan menikmati pula keunggulan kompetitif yang lebih baik. Kemungkinan-kemungkinan yang akan terjadi dari efek alokasi akan dijelaskan pada tabel dibawah ini :

Tabel 1. Keunggulan Kompetitif dan Spesialisasi Shift Share Esteban Marquillas

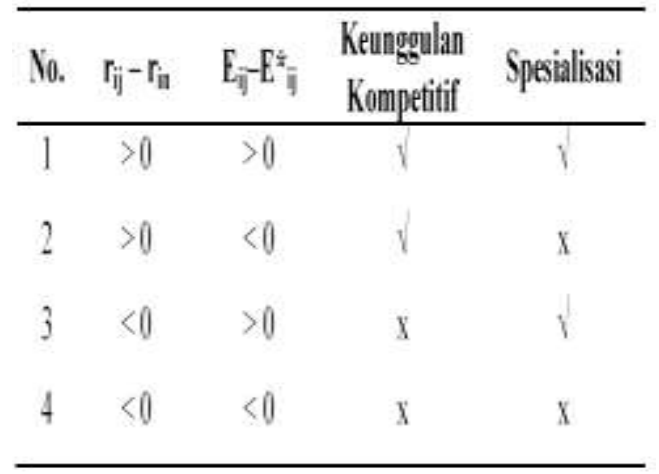

Sumber : Soepono (1993) 
Dari hasil modifikasi EstabanMarquillas terhadap analisis ShiftShare dapat dirumuskan sebagai berikut (Soepono, 1993):

$$
\begin{aligned}
D_{i j}= & E_{i j}\left(r_{n}\right)+E_{i j}\left(r_{i n}-r_{n}\right)+E_{i j}^{*}\left(r_{i j}-\right. \\
& \left.r_{i n}\right)+\left(E_{i j}-E_{i j}^{*}\right) \quad\left(r_{i j}-r_{i n}\right) \ldots(13)
\end{aligned}
$$

\section{Analisis Regresi Data Panel}

Struktur data yang digunakan dalam penelitian ini bersifat panel yaitu gabungan antara data cross sectionkota-kota dan time seriestahun. Alasan penggunaan data yang bersifat panel adalah menambah jumlah sampel. Semakin besar jumlah sampel yang digunakan, diharapkan estimator yang dihasilkan akan memiliki presisi yang lebih baik (varians semakin kecil) dan memiliki kekuatan statistik yang lebih tinggi

Ditinjau dari metode estimasi parameternya, model analisis data panel dapat dikelompokkan menjadi model dengan efek sama (common effect) dan model dengan efek individu (fixed dan random effect).

Tahap-tahap analisis data yang penulis lakukan untuk mandapatkan estimator yang terbaik bagi nilainilai parameter adalah sebagai berikut :

1). Memilih Model Analisis Data Panel Yang Terbaik

Pemilihan model analisis data panel yang terbaik dilakukan dengan dengan menggunakan Uji $F$ atau dengan menggunakan paket program Eviews (Uji Chow), dimana hasil kedua uji tersebut akan memberikan kesimpulan yang sama bagi penolakan maupun penerimaan $\mathrm{H}_{0}$. Hipotesis nol $\left(\mathrm{H}_{0}\right)$ dan hipotesis alternatif $\left(\mathrm{H}_{1}\right)$ untuk kedua pengujian tersebut adalah:

$\mathrm{H}_{0}: \alpha_{1}=\alpha_{2}=\ldots=\alpha_{n}$ (model common effect)

$\mathrm{H}_{1}: \alpha_{1} \neq \alpha_{2} \neq \ldots \neq \alpha_{n}$ (model dengan efek individu)

Pengujian hipotesa dengan uji F menggunakan statistik

$$
F_{n-1, n t-n-k}=\frac{\left(S S E_{1}-S S E_{2}\right) /(n-1)}{S S E_{2} /(n t-n-k)}
$$

Dimana :

$$
\begin{aligned}
S S E_{1}= & \text { sum of square error dari } \\
& \text { model common effect } \\
S S E_{2}= & \text { sum of square error dari } \\
& \text { model individual effect } \\
\mathrm{n} \quad= & \text { banyaknya cross section } \\
\mathrm{t} \quad= & \text { banyaknya titik waktu } \\
\mathrm{k} \quad= & \text { banyaknya variabel bebas }
\end{aligned}
$$

Kriteria pengujian bagi uji $\mathrm{F}$ adalah jika nilai $\mathrm{F}_{\text {hitung }}$ lebih besar dari $\mathrm{F}_{\text {tabel }}\left(F_{n-1, n t-n-k}(\alpha \%)\right)$, dengan $\alpha$ adalah tingkat siginifikansi, maka $\mathrm{H}_{0}$ ditolak dan model yang digunakan adalah model analisis data panel dengan efek individu.

Kriteria pengujian bagi uji $\mathrm{F}$ adalah jika nilai $F_{\text {hitung }}$ lebih besar dari $\mathrm{F}_{\text {tabel }}\left(F_{n-1, n t-n-k}(\alpha \%)\right)$, dengan $\alpha$ adalah tingkat siginifikansi, maka $\mathrm{H}_{0}$ ditolak dan model yang digunakan 
adalah model analisis data panel dengan efek individu.

Pemilihan model analisis data panel antara fixed effect atau random effect, selain dengan uji Hausman, juga dapat dilakukan secara teoritis. Bila $\mathrm{N}$ besar dan $\mathrm{T}$ kecil, maka hasil estimasi kedua pendekatan akan berbeda jauh. Jadi, apabila diyakini bahwa unit cross section yang dipilih diambil secara acak maka model random effect harus digunakan. Sebaliknya, apabila diyakini bahwa unit cross section yang dipilih tidak diambil secara acak maka harus menggunakan model fixed effect. Hal ini didukung oleh Green dan Turkey dalam Gelman (2005) yang menyatakan bahwa jika sampel hampir meliputi atau meliputi keseluruhan data populasi maka model analisis data panel yang digunakan adalah fixed effect. Baltagi (2007) juga menyarankan, pada data populasi akan lebih tepat bila menggunakan metodefixed effect. Meskipun estimator yang dihasilkan dari metode fixed effect tidak efisien dibanding ketika menggunakan metode random effect, namun estimator tersebut tetap unbias dan konsisten.

Jika keputusan yang diambil untuk melakukan analisa data panel adalah melalui fixed effect, maka langkah selanjutnya adalah menentukan struktur covariance residualnya apakah homoskedastisitas atau heteroskedastisitas tanpa cross section. Hasilnya akan menentukan metode estimator yang akan dipilih apakah no weighting (struktur homoskedastisitas) atau dengan weighting cross section weight (struktur heteroskedastisitas). Bila struktur matrik covariance residualnya adalah heteroskedastisitas, maka dapat dilakukan peningkatan efisiensi dengan menggunakan White Heteroscedasticity Consistent Standard Errors and Covariance.

2). Melakukan uji signifikansi

Setelah pemilihan model analisis data panel yang terbaik selesai dilaksanakan, dilakukan uji signifikansi yang terdiri dari

a. Uji Secara Serempak (Uji F) Uji serempak (uji F) dimaksudkan untuk melihat apakah seluruh variabel bebas yang ada dalam model secara bersama-sama mempengaruhi variabel tak bebas. Adapun langkahlangkah uji $\mathrm{F}$ adalah sebagai berikut:

1. Menetapkan hipotesa

$\mathrm{H}_{0}: \beta 1=\beta 2=. .=\beta \mathrm{n}=0 ;$
dimana variabel-variabel
bebas secara bersama-
sama
tidak
tak bebas
$\mathrm{H}_{1}: \beta 1 \neq \beta 2 \neq \ldots \neq \beta \mathrm{n} \neq 0$
Dimana paling sedikit
salah satu dari variabel-


variabel bebas mempengaruhi variabel tak bebas

2. Menetapkan daerah kritis dengan melihat F-tabel dan mencari nilai F-hitung kemudian menarik kesimpulan.

Jika nilai $\mathrm{F}$ hitung $>\mathrm{F}$ tabel atau nilai probabilitas $\mathrm{F}$ statistik $<$ taraf nyata $(\alpha)$, maka keputusan menolah H0 signifikan. Dengan menolak HO berarti variabel bebas secara bersama-sama signifikan berpengaruh nyata terhadap variabel tak bebas.

b. Uji Secara parsial (Uji t)

Uji parsial ditujukan untuk melihat apakah variabelvariabel bebas yang digunakan dalam model secara individual dapat mempengaruhi variabel tak bebas. Pengujian ini dilakukan dengan menggunakan uji tstatistik.Langkah-langkah pengujian t-statistik adalah sebagai berikut:

1. Membuat hipotesis

\begin{tabular}{|c|c|}
\hline $\begin{array}{l}\mathrm{H}_{0}: \quad \beta_{\mathrm{i}}=0 ; \quad \mathrm{d} \\
\text { variabel bebas } \\
\text { mempengaruhi } \\
\text { tak bebas }\end{array}$ & $\begin{array}{r}\text { di mana } \\
\text { tidak } \\
\text { variabel }\end{array}$ \\
\hline $\begin{array}{l}\mathrm{H}_{1}: \quad \beta_{\mathrm{i}} \neq 0 ; \quad \mathrm{d} \\
\text { variabel }\end{array}$ & $\begin{array}{r}\text { di mana } \\
\text { bebas }\end{array}$ \\
\hline $\begin{array}{l}\text { mempengaruhi } \\
\text { tak bebas }\end{array}$ & \\
\hline
\end{tabular}

2. Menetapkan daerah kritis melalui t-tabel dan mencari t-hitungkemudian menarik kesimpulan.

Jika nilai $\mathrm{t}$ hitung > t tabel atau nilai probabilitas $\mathrm{t}$ statistic $<$ taraf nyata $(\alpha)$, maka keputusan menolah H0 signifikan. Dengan menolak H0 berarti variabel bebas secara parsial signifikan berpengaruh nyata terhadap variabel tak bebas.

\section{HASIL DAN PEMBAHASAN}

Berdasarkan penghitungan rata-rata LQ Kota-Kota di Provinsi Sumatera Selatan Tahun 2006-2013 dari sisi tenaga kerja, diperoleh hasil bahwa bahwa tidak satu pun kota di Provinsi Sumatera Selatan terspesialisasi pada sektor pertanian. Untuk sektor industri nilai LQ menunjukkan sektor industri terspesialisasi di Kota Palembang, Prabumulih dan Lubuk Linggau, tetapi belum terspesialisasi di Kota Pagar Alam. Sedangkan sektor jasaterspesialisasi di seluruh kota di Provinsi Sumatera Selatan. 
Tabel 2.NilaiRata-Rata LQ Sektor Pertanian, Industri dan Jasa Kota-Kota di Provinsi SumateraSelatan Tahun 2006-2013

\begin{tabular}{|c|c|c|c|c|}
\hline Kota & \multicolumn{3}{|c|}{ Rata-Rata LQ } & \\
\hline & Sektor Pertanian & Sektor Industri & Sektor Jasa & \\
\hline Palembang & 0.05 & 1.91 & 2.52 & \\
\hline Prabumulih & 0.59 & 1.60 & 1.58 & \\
\hline Pagar Alam & 0.97 & 0.66 & 1.15 & \\
\hline Lubuk Linggau & 0.47 & 1.22 & 1.95 & \\
\hline
\end{tabular}

Sumber : BPS

Tabel 3. Nilai Spesialisasi Sektor Pertanian Kota-Kota di Provinsi Sumatera Selatan Berdasarkan Penghitungan Shift Share Esteban Marquillas Tahun 2013

\begin{tabular}{|l|c|c|c|c|c|c|c|c|}
\hline \multirow{2}{*}{ Kota } & \multicolumn{7}{|c|}{ Nilai Spesialisasi (Eij-E*ij) } \\
\cline { 2 - 9 } & 2006 & 2007 & 2008 & 2009 & 2010 & 2011 & 2012 & 2013 \\
\hline Palembang & Negatif & Negatif & Negatif & Negatif & Negatif & Negatif & Negatif & Negatif \\
\hline Prabumulih & Negatif & Negatif & Negatif & Negatif & Negatif & Negatif & Negatif Negatif \\
\hline Pagar Alam & Negatif & Positif & Positif & Positif & Positif & Negatif & Negatif Negatif \\
\hline ubuk \\
Linggau
\end{tabular}

Sumber: BPS

Kesempatan kerja sektor industri terspesialisasi di Kota Palembang, Prabumulih dan Lubuk Linggau. Untuk kota Pagar Alam, sektor industri belum terspesialisasi tetapi nilainya terus mengalami peningkatan dalam periode Tahun 2006-2011. Adapun penghitungan spesialisasi sektor industri dengan Shift Share Esteban Marquillas menghasilkan kesimpulan yang serupa dengan penghitungan LQ.

Tabel 4. Nilai LQ Sektor Industri Kota-Kota di Provinsi Sumatera Selatan

\begin{tabular}{|c|c|c|c|c|c|c|c|c|c|}
\hline \multirow{2}{*}{ Kota } & \multicolumn{7}{|c|}{ Nilai LQ } & \multirow{2}{*}{$\begin{array}{c}\text { Rata-Rata } \\
\text { LQ }\end{array}$} \\
\cline { 2 - 11 } & 2006 & 2007 & 2008 & 2009 & 2010 & 2011 & 2012 & 2013 & \\
\hline Palembang & 1.25 & 1.96 & 1.70 & 2.03 & 2.08 & 2.12 & 2.17 & 1.95 & 1.91 \\
\hline Prabumulih & 1.81 & 1.39 & 1.34 & 1.41 & 1.62 & 2.11 & 1.81 & 1.28 & 1.60 \\
\hline Pagar Alam & 0.60 & 0.40 & 0.66 & 0.65 & 0.45 & 0.84 & 0.80 & 0.90 & 0.66 \\
\hline $\begin{array}{c}\text { Lubuk } \\
\text { Linggau }\end{array}$ & 1.36 & 1.36 & 1.24 & 1.31 & 1.41 & 1.17 & 1.07 & 0.83 & 1.22 \\
\hline
\end{tabular}

Sumber: BPS 
Tabel 5. Nilai Spesialisasi Sektor Industri Kota-Kota di Provinsi Sumatera Selatan Berdasarkan Penghitungan Shift Share Esteban Marquillas

\begin{tabular}{|c|c|c|c|c|c|c|c|c|}
\hline \multirow{2}{*}{ Kota } & \multicolumn{7}{|c|}{ Nilai Spesialisasi (Eij-E*ij) } \\
\cline { 2 - 9 } & 2006 & 2007 & 2008 & 2009 & 2010 & 2011 & 2012 & 2013 \\
\hline Positif & Positif & Positif & Positif & Positif & Positif & Positif & Positif & \\
\hline Positif & Positif & Positif & Positif & Positif & Positif & Positif & Positif & \\
\hline Negatif & Negatif & Negatif & Negatif & Negatif & Negatif & Negatif & Negatif & \\
\hline Negatif & Positif & Positif & Positif & Positif & Positif & Positif & Positif & \\
\hline
\end{tabular}

Sumber : BPS

Berdasarkan penghitungan nilai LQ dan Shift Share Esteban Marquillas sektor jasa tahun 20062013, diperoleh hasil yang menunjukkan bahwa kesempatan kerja sektor ini terspesialisasi di kota-kota, dengan nilai LQ terbesar di Kota Palembang.

Sektor jasa terspesialisasi di seluruh kota di Provinsi Sumatera Selatan, terlihat dari nilai LQ yang bernilai lebih dari 1. Nilai LQ sektor jasa terbesar di Kota Palembang dengan nilai LQ lebih besar dari 2. Penghitungan nilai spesialisasi sektor jasa dengan Shift Share Esteban Marquillas menghasilkan kesimpulan yang sama dengan penghitungan menggunakan LQ yaitu menghasilkan nilai spesialisasi yang positif.

Tabel 6.Nilai LQ Sektor Jasa Kota-Kota di Provinsi Sumatera Selatan

\begin{tabular}{|c|c|c|c|c|c|c|c|c|c|}
\hline \multirow{2}{*}{ Kota } & \multicolumn{7}{|c|}{ Nilai LQ } & \multirow{2}{*}{$\begin{array}{c}\text { Rata-Rata } \\
\text { LQ }\end{array}$} \\
\cline { 2 - 9 } & 2006 & 2007 & 2008 & 2009 & 2010 & 2011 & 2012 & 2013 & \\
\hline Palembang & 3.11 & 2.75 & 2.55 & 2.50 & 2.40 & 2.33 & 2.28 & 2.21 & 2.52 \\
\hline Prabumulih & 1.54 & 1.67 & 1.58 & 1.55 & 1.45 & 1.61 & 1.64 & 1.63 & 1.58 \\
\hline $\begin{array}{c}\text { Pagar } \\
\text { Alam }\end{array}$ & 1.16 & 0.99 & 1.08 & 1.09 & 1.15 & 1.22 & 1.24 & 1.28 & 1.15 \\
\hline $\begin{array}{c}\text { Lubuk } \\
\text { Linggau }\end{array}$ & 2.18 & 2.10 & 1.99 & 2.08 & 1.89 & 1.72 & 1.82 & 1.84 & 1.95 \\
\hline
\end{tabular}

Sumber : BPS, diolah 
Tabel 7. Nilai Spesialisasi Sektor Jasa Kota-Kota di Provinsi Sumatera Selatan berdasarkan penghitungan Shift Share Esteban Marquilass

\begin{tabular}{|c|c|c|c|c|c|c|c|c|}
\hline \multirow{2}{*}{ Kota } & \multicolumn{7}{|c|}{ Nilai Spesialisasi (Eij-E*ij) } \\
\cline { 2 - 9 } & 2006 & 2007 & 2008 & 2009 & 2010 & 2011 & 2012 & 2013 \\
\hline Palembang & Positif & Positif & Positif & Positif & Positif & Positif & Positif & Positif \\
\hline Prabumulih & Positif & Positif & Positif & Positif & Positif & Positif & Positif & Positif \\
\hline $\begin{array}{c}\text { Pagar } \\
\text { Alam }\end{array}$ & Positif & Negatif & Positif & Positif & Positif & Positif & Positif & Positif \\
\hline $\begin{array}{c}\text { Lubuk } \\
\text { Linggau }\end{array}$ & Positif & Positif & Positif & Positif & Positif & Positif & Positif & Positif \\
\hline
\end{tabular}

Sumber : BPS, diolah

Pengaruh Perubahan Struktur Ekonomi Terhadap Spesialisasi Sektoral dengan Metode Location Quotient ( $L Q)$

\section{a. Sektor Pertanian}

Hasil penghitungan regresi antara variabel perubahan struktur ekonomi dengan spesialisasi sektoral diperoleh hasil bahwa untuk sektor pertanian, perubahan struktur ekonomi sektor pertanian berpengaruh signifikan terhadap spesialisasi sektoral. Nilai koefisien determinasi sebesar 0,35 berarti 35 persen variasi variabel spesialisasi sektoral sektor pertanian dipengaruhi oleh variabel perubahan struktur ekonomi sektor pertanian. Sisanya yaitu sebesar 65 persen dijelaskan oleh variabel lain di luar model. Sehingga model Spesialisasi Sektor Pertanian dengan metode LQ adalah sebagai berikut:

$$
\mathrm{Sp}(\mathrm{LQ})=0,2698+0,0237 \text { PDRBp }
$$

\section{b. Sektor Industri}

Untuk sektor industri, penghitungan regresi antara variabel perubahan struktur ekonomi dengan spesialisasi sektoral metode LQ mendapatkan hasil yang signifikan dan negatif. Hal ini berarti dengan metode LQ perubahan struktur ekonomi sektor industri berpengaruh terhadap spesialisasi sektoral sektor industri kota-kota di Provinsi Sumatera Selatan. Nilai R kuadrat sebesar 0,83 berarti 83 persen variasi spesialisasi sektor industri di KotaKota di Provinsi Sumatera Selatan dapat dijelaskan oleh variabel perubahan struktur ekonomi sektor industri. Sisanya sebesar 17 persen dijelaskan oleh variabel lain di luar model. Adapun model Spesialisasi Sektor Industri dengan metode LQ adalah sebagai berikut:

$$
\text { Si }(\text { LQ) = 2,4191- 0,0285 PDRBi }
$$

\section{c. Sektor Jasa}

Pada model sektor jasa dengan metode LQ diperoleh kesimpulan bahwa perubahan struktur ekonomi sektor jasa berpengaruh signifikan dalam arah yang negatif terhadap spesialisasi sektoral sektor jasa. Nilai 
koefisien determinasi yang diperoleh adalah 0,13 yaitu bahwa variasi perubahan struktur ekonomi sektor jasa berpengaruh terhadap variasi spesialisasi sektoral sektor jasa sebesar 13 persen, sisanya sebesar 87 persen dijelaskan oleh variabel lain di luar model. Model spesialisasi sektor jasa dengan LQ adalah sebagai berikut :

$$
\text { Sj }(L Q)=3,031-0,0237 \text { PDRBj }
$$

Jika mencermati model regresi sektor jasa dengan metode LQ, nilai konstanta yang sangat besar mencerminkan bahwa untuk kotakota di Provinsi Sumatera Selatan, sektor jasa akan tetap terspesialisasi meskipun terjadi perubahan pada variabel perubahan struktur ekonomi. Jadi meskipun koefisien bertanda negatif tetapi nilai konstanta yang besar menunjukkan bahwa kenaikan maupun penurunan kontribusi sektor jasa, sektor jasa tetap terspesialisasi di kota-kota. Hal ini makin menguatkan kesimpulan bahwa sektor jasa identik dengan perkotaan.

Hasil penelitian menunjukkan bahwa perubahan struktur ekonomi berpengaruh terhadap penyerapan tenaga kerja. Pengaruh ini terjadi di tiap sektor, baik sektor pertanian, sektor industri maupun sektor jasa. Hal ini juga menunjukkan bahwa kenaikan maupun penurunan dalam kontribusi PDRB sektor pertanian, sektor industri maupun sektor jasa akan merubah penyerapan tenaga kerja tiap sektor tersebut.
Pengujian kesesuaian model $\left(\mathrm{R}^{2}\right)$ menunjukkan bahwa model estimasi tergolong cukup baik.Ini terlihat dari nilai $\mathrm{R}$ kuadrat yang cukup tinggi. Nilai $\mathrm{R}$ kuadrat sektor pertanian sebesar 68 persen. Artinya variasi penyerapan tenaga kerja sektor pertanian dapat dijelaskan oleh perubahan struktur ekonomi sektor pertanian sebesar 68 persen, sedangkan sisanya sebesar 32 persen dijelaskan faktor lain di luar model. Nilai R kuadrat sektor industri adalah 91 persen. Artinya bahwa variabel penyerapan tenaga kerja sektor industri dapat dijelaskan oleh variabel perubahan struktur ekonomi sektor industri sebesar 91 persen, sisanya sebesar 9 persen dijelaskan variabel lain di luar model. Pada sektor jasa nilai $\mathrm{R}$ kuadrat mencapai 98 persen, artinya 98 persen variasi penyerapan tenaga kerja sektor jasadapat dijelaskan oleh variabel perubahan struktur ekonomi sektor jasa. Sisanya sebesar 2 persen dijelaskan oleh variabel lain di luar model.

Sektor jasa berpengaruh signifikan dan positif terhadap penyerapan tenaga kerja. Dengan tingkat kepercayaan 99 persen kita dapat menyimpulkan bahwa kenaikan kontribusi sektor jasa akan meningkatkan penyerapan tenaga kerja sektor tersebut khususnya di kota-kota di Provinsi Sumatera Selatan. Sebagaimana yang telah diketahui bahwa tingkat pengangguran kota-kota di Provinsi 
Sumatera Selatan lebih tinggi jika dibandingkan tingkat pengangguran kabupaten-kabupaten, sehingga solusi dalam mengatasi pengangguran di kota yaitu dengan meningkatkan nilai tambah sektor jasa agar lebih banyak penduduk yang dapat bekerja di sektor ini. Adapun model penyerapan tenaga kerja sektor pertanian, industri dan sektor jasa yang diperoleh dalam penelitian ini adalah sebagai berikut:

\section{Model Penyerapan Tenaga Kerja Sektor Pertanian TKp $=16437,55+574,8682$ DRBp} Besarnya potensi sektor pertanian dalam menyerap tenaga kerja diimbangi oleh besarnya potensi sektor pertanian di Provinsi Sumatera Selatan. Berdasarkan data Statistik Indonesia 2014 yang diterbitkan BPS, Provinsi Sumatera Selatan memiliki luas lahan sawah terbesar di Pulau Sumatera, dan nomor 4 terbesar se-Indonesia (617.916,20 ha). Dalam hal potensi perkebunan, Provinsi Sumatera Selatan merupakan Provinsi yang memiliki luas areal tanaman perkebunan kelapa sawit nomor 5 seIndonesia (941,1 ha) dan luas perkebunan karet terbesar seIndonesia (685,6 ha). Selain kelapa sawit dan karet, potensi perkebunan Sumatera Selatan juga pada komoditi kopi, dimana Provinsi Sumatera Selatan memiliki luas areal perkebunan kopi terbesar di Indonesia (253,4 ha). Pada budidaya perikanan, Provinsi Sumatera Selatan juga unggul dengan memiliki luas area budidaya perikanan kolam terbesar ke-2 di Indonesia setelah Provinsi Banten.

\section{Model Penyerapan Tenaga Kerja Sektor Industri TKi = 62196,83 - 813,611 PDRBi \\ Koefisien untuk pengujian} sektor industri bernilai negatif, sehingga kita dapat mengartikan bahwa transformasi ekonomi berupa kenaikan kontribusi PDRB sektor industri untuk kota-kota di Provinsi Sumatera Selatan tidak berjalan searah dengan penyerapan tenaga kerja di sektor industri. Hal ini dimungkinkan karena semakin besar sebuah industri maka akan menggunakan teknologi yang lebih canggih sehingga penggunaan tenaga kerja di sektor industri menjadi berkurang. Selain itu jika melihat pada besarnya nilai tambah sektor industri Tahun 2013 Kota Palembang merupakan kota dimana nilai sektor industrinya paling besar, yakni mencapai 92 persen dari keseluruhan nilai tambah sektor industri kota-kota di Provinsi Sumatera Selatan, dan sebagian besar nilai tambah sektor industri di Kota Palembang bersumber dari pengilangan minyak bumi.

Dalam lingkup Provinsi Sumatera Selatan, sektor industri merupakan sektor andalan dalam hal kontribusinya terhadap PDRB. Berdasarkan data BPS Tahun 2013, sektor industri merupakan 
kontributor utama PDRB Provinsi Sumatera Selatan, disusul sektor jasa dan terakhir sektor pertanian. Besarnya kontribusi sektor industri terhadap PDRB tidak diimbangi dengan kemampuannya dalam menyerap tenaga kerja. Sampai dengan Tahun 2013 sektor pertanian tetap menjadi sektor utama dalam hal penyerapan tenaga kerja di Provinsi Sumatera Selatan, terlihat dari besarnya penyerapan tenaga kerja sektor pertanian yang mencapai 54,69 persen.

Mencermati besarnya potensi sektor pertanian di Provinsi Sumatera Selatan dan besarnya kemampuan sektor pertanian dalam penyerapan tenaga kerja di Provinsi Sumatera Selatan, maka kota-kota di Provinsi Sumatera Selatan seyogyanya mengembangkan sektor industri dengan berbasis pada sektor pertanian sehingga potensi pertanian yang ada di Provinsi Sumatera Selatan dapat dikembangkan secara maksimal.

\section{Model Penyerapan Tenaga Kerja Sektor Jasa TKj = 41558,85+1761,17PDRBj}

Dari model penyerapan tenaga kerja sektor jasa didapatkan kesimpulan bahwa setiap kenaikan 1 persen kontribusi sektor jasa akan menaikkan penyerapan tenaga kerja sektor jasa sebanyak 1761 orang. Koefisien bertanda positif yang artinya perubahan struktur ekonomi sektor jasa di kota-kota di Provinsi
Sumatera Selatan berjalan searah dengan perubahan struktur penyerapan tenaga kerja sektor jasa. Dengan meningkatkan kontribusi sektor jasa, penyerapan tenaga kerja sektor ini menjadi bertambah.

Sektor Jasa yang memegang peranan penting dalam penciptaan nilai tambah berdasarkan data pada tabel 4.18 adalah sektor Perdagangan, Hotel dan Restoran sub sektor Perdagangan Besar dan Eceran serta sektor Jasa-Jasa sub sektor Jasa Pemerintahan dan Pertahanan.

Berdasarkan data distribusi persentase PDRB sektor jasa KotaKota di Provinsi Sumatera Selatan Tahun 2013 untuk Kota Prabumulih, pengembangan sektor pengangkutan dan komunikasi harus lebih ditingkatkan karena kontribusi sektor ini paling kecil jika dibandingkan kontribusinya di Kota Palembang, Lubuk Linggau dan Pagar Alam. Sub sektor lain yang perlu mendapatkan perhatian untuk lebih ditingkatkan peranannya di masa mendatang adalah sektor jasa-jasa sub sektor hiburan dan rekreasi yang kontribusinya tidak sampai 0,5 persen terhadap PDRB masingmasing kota. Sementara itu pengembangan sektor/sub sektor unggulan di kota-kota di Provinsi Sumatera Selatan harus terus ditingkatkan karena sektor/sub sektor tersebut memiliki kapasitas dalam menciptakan lapangan pekerjaan di perkotaan. 


\section{KESIMPULAN DAN SARAN}

Hasil analisis penelitian ini mendapatkan kesimpulan sebagai berikut :Hasil estimasi dengan regresi panel menunjukkan bahwa perubahan struktur ekonomi sektor pertanian berpengaruh signifikan dan positif terhadap spesialisasi sektor pertanian. Perubahan struktur ekonomi sektor industri berpengaruh signifikan dan negatif terhadap spesialisasi sektor industri. Untuk sektor jasa diperoleh kesimpulan bahwa perubahan struktur ekonomi sektor jasa berpengaruh signifikan dan positif terhadap spesialisasi sektor jasa. Pada periode Tahun 2006-2013 untuk Kota-Kota di Provinsi Sumatera Selatan secara keseluruhan, perubahan struktur ekonomi berpengaruh signifikan terhadap penyerapan tenaga kerja sektoral. Untuk sektor pertanian dan jasa, perubahan struktur ekonomi yang terjadi berpengaruh dalam arah yang positif dengan penyerapan tenaga kerja, sedangkan untuk sektor industri perubahan struktur ekonomi berpengaruh signifikan dan negatif terhadap penyerapan tenaga kerja sektoral.

Peneliti memberikan saran untuk itu perlu meningkatkan peranan sektor jasa di Kota-Kota di Provinsi Sumatera Selatan karena sektor jasa merupakan penggerak perekonomian, kontributor utama PDRB Kota-Kota serta memiliki peran strategis dalam penciptaan lapangan kerja. Pemerintah Daerah agar mendorong peranan sektor jasa serta memberikan fasilitas bantuan permodalan kepada masyarakat yang ingin mengembangkan sektor ini.

\section{DAFTAR PUSTAKA}

Badan Pusat Statistik Provinsi Sumatera Selatan, 2014. Buku Saku Data dan Indikator Sosial Sumatera Selatan Tahun 2006-2013. Palembang

Badan Pusat Statistik Provinsi Sumatera Selatan,2014. Indikator Kesejahteraan Rakyat Sumatera Selatan 2013. Palembang

Badan Pusat Statistik Provinsi Sumatera Selatan,20062013. Pendapatan Domestik Regional Bruto Kabupaten/Kota di Provinsi Sumatera Selatan. Palembang

Kien, Nguyen Trung, 2014. Employment Transformation in the Vietnamese Economy in Light of the Lewis -FeiRanis Growth Model of A Labor-Abundant Economy. Journal of Economics and Development, Vol 16 No 3 December 2014 pp 49-67.

Kingombe, Christian dan te Velde, Dirk Willem, 2013. Structural Transformation and Employment Creation: The role of growth facilitation policies in Sub-Saharan Africa. Background Paper For The World Development Report 2013. 
Kusreni, Sri, 2009. Pengaruh Perubahan Struktur Ekonomi Terhadap Spesialisasi Sektoral danWilayah serta Struktur Penyerapan Tenaga Kerja Sektoral Untuk Daerah Perkotaan diJawa Timur. Majalah Ekonomi, Fakultas Ekonomi Universitas Airlangga, Tahun XIX No 1 April 2009

Liwen, Chen; Xiangquan, Zeng; Yumei, Yang, 2011. Rural Labor Absorption Efficiency in Urban Areas under Different Urbanization Patterns and Industrial Structures : The Case of China. Discussion Paper Series IZA DP No. 6189.

Purba, Elvis, 2007. Tipologi Pertumbuhan dan Spesialisasi Regional Kabupaten-Kabupaten diPantai Timur Sumatera Utara, VISI (2007) 15 (3) 226-235.

Ray, Debraj, 1998. Development Economics. Princeton University Press New Jersey

Todaro, Michael $\mathrm{P}$ and Stephen Smith, 2000. Pembangunan Ekonomi di Dunia Ketiga, Terjemahan, Jakarta . PT Erlangga

Walpole, Ronald E, 1995. Pengantar Statistika Edisi ke-3, Terjemahan, Jakarta. PT Gramedia

Wibowo, Tri, 2013. Analisis Pertumbuhan, Penyerapan Tenaga Kerja dan

Yunisvita, 2011. Transformasi Struktur Ketenagakerjaan dan
Pertumbuhan Ekonomi Sumatera Selatan, Jurnal Ekonomi Pembangunan, Fakultas Ekonomi Universitas Sriwijaya, Volume 9 Nomor 2 Hal 90-99 